Beskattning af aktiebolags vinst genom inkomstskatt

Author(s): David Davidson

Source: Ekonomisk Tidskrift, Årg. 21, häft 1 (1919), pp. 15-27

Published by: Wiley on behalf of The Scandinavian Journal of Economics

Stable URL: http://www.jstor.org/stable/3437461

Accessed: 27-06-2016 04:15 UTC

Your use of the JSTOR archive indicates your acceptance of the Terms \& Conditions of Use, available at

http://about.jstor.org/terms

JSTOR is a not-for-profit service that helps scholars, researchers, and students discover, use, and build upon a wide range of content in a trusted digital archive. We use information technology and tools to increase productivity and facilitate new forms of scholarship. For more information about JSTOR, please contact support@jstor.org.

Wiley, The Scandinavian Journal of Economics are collaborating with JSTOR to digitize, preserve and extend access to Ekonomisk Tidskrift 


\title{
Beskattning af aktiebolags vinst genom inkomstskatt.
}

\author{
Af David Davidson.
}

Denna fråga bragtes åter på dagordningen hos oss genom en kunglig proposition till 1918 års riksdag. Där behandlades visserligen blott några särskilda punkter rörande aktiebolagens beskattning, men det framhölls, att den egentliga orsaken till de bristfälligheter, som genom regeringens förslag skulle undanröjas, låge $\mathrm{i}$ att de hos oss tillämpade principerna för aktiebolags beskattning genom inkomstskatt vore felaktiga.

Detta antagande har stor sannolikhet för sig, redan rent statistiskt sedt. Såsom jag $\mathrm{i}$ en uppsats $\mathrm{i}$ denna tidskrift årg. I90I sid. 435 o. ff. meddelade, tillämpades då $i$ de positiva lagstiftningarna icke mindre än åtta olika regler beträffande den principiella frågan om och $\mathrm{i}$ hvad mån aktieägarna eller aktiebolaget borde beskattas för aktiebolagets vinst. Under sådana förhållanden vore det ju en lycklig slump, om den regel, som i vårt land valts, vore den rätta.

Lösningen af nyssnämnda fråga förutsätter utredningen af en annan, nämligen det ekonomiska förhållandet mellan aktiebolagets vinst och aktieägarnas inkomster från bolaget.

Härvid kunde det synas ligga nära till hands att tillägga afgörande betydelse åt den juridiska konstruktionen af rätta förhållandet mellan aktiebolaget och aktieägarna. Men redan af det skäl att enighet angående denna punkt ej råder bland de rättslärde och det här ej kan komma ifråga att ingå på någon diskussion om detta kvistiga problem, måste jag inskränka mig till att undersöka, hvilken betydelse de olika hufvuduppfattningarna angăende denna fråga kunna ha för lösningen af här ifrågavarande problem. De alternativ, som härvid behöfva beaktas, äro följande:

I) Aktiebolaget betraktas såsom ett i förhållande till aktieägarna fullt själfständigt rättssubjekt.

A) Rättsförhållandet mellan aktiebolaget och aktieägarna kunde då uppfattas $\mathrm{i}$ analogi med rättsförhăllandet mellan borgenär och gäldenär. I sitt arbete »Aktienwesen und Spekulation» har v. Petrazyki urgerat denna uppfattning. Aktieägarens ställning skiljer sig dock enligt P. från en vanlig borgenärs i följande afseenden. En borgenär erhåller en bestämd årlig ränta å sin kapitalfordran, under det att aktieägarens årsränta är växlande och kan vara mycket växlande - mellan noll och ett obestäm. bart maximum - i det att denna ränta är beroende bl. a. af storleken 
af aktiebolagets vinst. Det härskar dock icke full proportionalitet mellan aktieägarnas årsränta och aktiebolagets vinst, hvilket beror ej blott på de för aktiebolagens förvaltning gällande rättsbestämmelserna, som dels icke fordra, dels förhindra full dylik proportionalitet, utan ock på faktiska förhållanden, såsom t. ex. den icke ovanliga kutymen att föra bolagets räkenskaper på sådant sätt, att de uppvisa en mindre eller större vinst än den verkliga $\mathrm{i}$ syfte att därigenom inverka på utdelningens storlek, så att den blir mindre eller större än bolagets vinst tillåter. - En borgenär har vidare en bestämd kapitalfordran. Aktieägarens kapitalfordran är ju också formellt bestämd till ett visst belopp, men realiter är dess storlek obestämd. Hvad aktieägaren har att erhålla $\mathrm{i}$ kapital vid bolagets upplösning är icke det belopp, hvarå aktien lyder, utan vanligen ett större eller mindre belopp allt efter storleken af bolagets förmögenhet vid upplösningen. Och under bolagets bestånd beror värdet af aktieägarens kapitalfordran på de gällande börskurserna, och detta behöfver ej vara öfverensstämmande med det som vid en blifvande upplösning af bolaget kan utfalla på aktien. Visserligen föreligger sistnämnda förhållande äfven beträffande obligationer, men i så betydligt lägre grad än vid aktier, att denna skillnad, ehuru till formen blott en gradskillnad, $i$ verkligheten dock blir en artskillnad. I följd häraf kan under aktiebolagets bestånd kapitalvärdet af aktierna vara betydligt högre eller lägre än aktiebolagets kapitalförmögenhet; när aktiebolagets förmögenhet aftar, kunna aktiernas värde tilltaga, såsom $t$. ex. om bolaget utdelar stora dividender, som i grunden tas ur bolagets förmögenhet, och aktiernas kursvärde därigenom stiger. Petrazyki framhåller likheten i detta hänseende mellan aktiers och lotterilotters värdebildning. Summan af de särskilda lotternas faktiska värden är i regeln större än värdet af det utlottade. - Slutligen - och detta står i nära samband med det rörande aktieägarnas kapitalfordran sagda - kommer, i händelse af bolagets obestånd, aktieägarnas rätt att utfå sitt kapital efter öfriga borgenärers.

Till närmare belysning af denna analogi kunde $P$. ha hänvisat till den rättsliga karaktären af preferensaktier och kommanditlotter, som i alla nu berörda afseenden intaga en mellanställning mellan egentliga aktier och obligationer.

Vidare är att anmärka, att värdebildningen å aktier under aktiebolagets bestånd och värdebildningen å obligationer ej alltid äro så artskilda som P. antar. $\AA$ ena sidan finnas ju aktier, hvilkas värdebildning är undandragen spekulationens inverkan och sker så godt som uteslutande under inflytande af aktiebolagets verkliga förmögenhetsställning. $\AA$ andra sidan finnas obligationer, hvilkas värdebildning står under starkt inflytande af spekulationen, nämligen om gäldenärens solvens är osäker eller ändras. Detta innebär emellertid ej något inkast mot Petrazykis skrift, som i förbigående sagdt ej berör frågan om det rätta sättet för beskattning af aktiebolags vinst. Vidare må erinras om obligationer med uppskjuten ränta, dels obligationer med kapitalrabatt (där det kapital som återbetalas är större än det kapital som utlånats), dels obligationer med under tidens lopp väx- 
lande ränta (t. ex. under första hälften af lånetiden 5 procent, under den senare 6 procent). Dessa obligationer förete en likhet med aktier: utdelas $\mathrm{i}$ det hela bolagets hela vinst och med så vidt möjligt samma dividend hvarje år, närmar sig aktiernas karaktär vanliga obligationer. Utdelas åter endast en del af vinsten och med växlande dividender, bli aktierna lika obligationer med kapitalrabatt och växlande ränta.

Lägges nu berörda uppfattning till grund för alstiebolagens beskattning genom inkomstskatt, skulle regeln bli denna. Om ett aktiebolag har skulder, beskattas bolagets fordringsägare för räntan som till dem utbetalas, och bolaget får sin vinst minskad med denna ränta. Beskattningen af fordringsägarna för räntan är därvid oberoende af, om bolaget det ifrågavarande året har någon vinst eller ej, fordringsägarna bli skattskyldiga.äfven om medlen för räntans betalande måste tagas ur föregående års vinster, för hvilka bolaget redan erlagt skatt, eller eljest ur bolagets kapitaltillgångar. I analogi härmed borde aktieägarna för hvarje år beskattas för utdelningen till dem och aktiebolaget för sin årsvinst efter afdrag af utdelningen. Aktieägarnas skattskyldighet är därvid ej beroende af att utdelningen för året tas ur bolagets vinst samma år; äfven om utdelningen tas ur från föregående år reserverade vinster eller ur bolagets kapitaltillgångar i öfrigt, äro aktieägarna skattskyldiga för utdelningen.

När en bolagets fordringsägare făr sin kapitalfordran betald, blir han ej skattskyldig för denna. Beträffande aktieägaren motsvaras denna återbetalning af skuldkapitalet af bolagets upplösning; hvad aktieägaren då erhåller, blir alltså icke till någon del beskattningsbart som inkomst. Visserligen kan aktieägaren vid upplösningen af bolaget få mer än han insatt, men detta är ju enligt Petrazykis teori utmärkande för det särskilda slags fordringsförhållande, hvari aktieägaren står till bolaget.

Enligt dessa regler behöfver icke samma vinstbelopp bli beskattadt såväl hos bolaget som hos aktieägarna. Utdelar ett bolag hvarje år hela sin vinst, bli ju endast aktieägarna skattskyldiga. Utdelar bolaget alltid mindre än sin årsvinst, kommer skattskyldigheten för bolagets vinst att fördelas mellan aktiebolaget och aktieägarna. Detta kan ju materiellt leda till annat skattebelopp än om ständigt hela räntan utdelades, men någon dubbel beskattning af samma vinstdel föreligger icke. Dock kan en sådan dubbel beskattning inträffa, nämligen om ett bolag, som i allmänhet ej utdelar hela sin vinst utan reserverar en del däraf, dock därefter tidtals ger extra utdelningar ur de reserverade vinstmedlen, hvilka då bli beskattade både hos bolaget och hos delägarna. Däremot är det icke möjligt för bolaget att undandraga någon del af sin vinst från beskattning, enär ju bolaget själft skall erlägga skatt för all vinst som ej utdelas. Den egendomligheten hos det quasi-fordringsförhållande, som enligt den här behandlade uppfattningen förefinnes mellan aktieägarna och aktiebolaget, nämligen att bolaget (gäldenären) äger hvarje år bestämma huru mycket det skall betala i ränta till sina fordringsägare - aktieägarna -

2- 195. Ekonomisk Tidskrift 19ro. Häft. I 
och därigenom äfven huru stor kapitalbetalningen vid skuldförhållandets upplösning skall blifva, spelar ingen roll för skattskyldigheten för bolagets vinst, lika litet som det för storleken af en vanlig gäldenärs och hans fordringsägares sammanlagda skattskyldighet spelar năgon roll, on räntan å skulden är högre eller lägre; enda skillnaden blir att den ena får skatta för ett mindre belopp och den andra för ett större. ${ }^{1}$

Denna metod är i öfrigt fri från de olösliga komplikationer, som vidhäfta vår nuvarande lagstiftning och af hvilka några gifvit anledning till förutnämnda regeringsförslag. Utdelning af gratisaktier, som ju i ekonomiskt afseende blott är af formell natur, vållar inga materiella svărigheter, d. v. s. denna åtgärd spelar enligt denna metod ingen roll i frăga om beskattning af aktiebolags vinst. Betraktas utdelningen af gratisaktier såsom utdelning af vinst, får ju aktiebolaget vid beräkning af sin beskattningsbara inkomst göra afdrag för motsvarande belopp.

B) I en uppsats i Finanz-Archiv årg. 1904, sid. 545 o. ff. har Dehlinger sökt göra gällande, att mellan aktiebolagets vinst och utdelningen till aktieägarna finnes icke ens det rättsliga samband, som äger rum mellan en gäldenärs inkomst och de skuldräntor, som han betalar till sina fordringsägare. Den juridiskt-teoretiska grundvalen för hans teori är skäligen dimmig. Den sammanfattas i satsen: »das Recht der Aktionäre ist in dieser Hinsicht vielmehr nur ein Mitgliedsrecht, bestehend in dem Recht auf Dividende, d. h. auf einen Antheil am Reingewinn, falls die Gesellschaft einen solchen überhaupt erzielt, also nur in einem Anteilsrecht.» Förhållandet mellan aktiebolagets vinst och utdelningen till aktieägarna uppfattar han $i$ analogi med $t$. ex. förhållandet mellan patienternas och läkarens inkomst. Läkarens inkomst härrör ur patienternas inkomster, ur de honorar dessa betala honom. Men ändock betraktas dessa inkomster i beskattningshänseende săsom i förhållande till hvarandra fullt själfständiga. Att aktieägarnas utdelningar härröra ur aktiebolagets vinst, är sålunda ej något skäl för att icke betrakta dessa utdelningar såsom $\mathrm{i}$ förhållande till aktiebolagets vinst fullt själfständiga inkomster. På grund häraf kommer Dehlinger till det resultat, att aktiebolaget bör beskattas för hela sin vinst och aktieägarna för utdelningen från bolaget, eller den princip som tillämpas $i$ vår inkomstskatt. Någon dubbel beskattning af samma inkomst uppkommer enligt $\mathrm{D}$. härigenom icke.

1 Om ett bolag under tidernas lopp utdelar sammanlagdt mer än sin sammanlagda vinst under samma tid och sålunda för dessa utdelningar angriper det inbetalta aktiekapitalet, kommer skattskyldighet att äga rum för mer än bolagets vinst. Motsvarande fall kan emellertid äfven inträda vid ett vanligt skuldförhållande, ifall gäldenärens inkomst ej räcker till att betala hans skuldräntor, utan gäldenärens förmögenhet måste tillgripas för räntornas betalning. Ett annat dylikt fall föreligger enligt vår lag, ifall en gäldenär återbetalar sin skuld $\mathrm{i}$ form af lifräntor till borgenärerna, hvilket ju innebär, att dessa borgenärer få erlägga inkomstskatt ej blott för den egentliga räntan å sina fordringar, utan äfven å de belopp, som i sak utgöra afbetalning à deras kapitalfordringar. 
Dehlingers motivering af att aktieägares utdelning representerar en i ekonomiskt afseende själfständig inkomst i förhållande till aktiebolagets vinst är dock ej tillfredsställande. Den hvilar på en gammal nu öfvergifven felaktig distinktion mellan ursprungliga och härledda inkomster, enligt hvilken nationalprodukten först $\mathrm{i}$ sin helhet uppdelades $\mathrm{i}$ de ursprungliga inkomsterna och de härledda därefter uppstode därigenom att ägarna af de ursprungliga inkomsterna afstode en del af dessa ăt andra; summan af de ursprungliga och de härledda inkomsterna blefve sålunda alltid större än nationalprodukten eller nationalinkomsten. $\mathrm{Nu}$ finnes det visserligen härledda inkomster $\mathrm{i}$ denna bemärkelse, $t$. ex. då en person lämnar en annan ett årligt underhåll; genom denna akt uppstår ej någon ny inkomst, d. v. s. underhållsgifvarens och underhållstagarens verkliga sammanlagda inkomst är ej större än den förres inkomst, innan han åtog sig att lämna underhållet. Vid beskattningen beskattas därför antingen underhållsgifvaren ensam för hela sin ursprungliga inkomst eller ock beskattas underhållstagaren för understödet, men då får underhållsgifvaren göra afdrag för det lämnade underhållet. Den ofvannämnda teorien fattade emellertid begreppet ursprunglig inkomst och begreppet nationalprodukt alltför trångt. Det betraktelsesätt, hvarifrån denna teori utgick, var följande. Genom samverkan af ett lands arbetare, jordägare, kapitalister och företagare åstadkoms en totalprodukt, som i vissa proportioner fördelades mellan nämnda deltagare $\mathrm{i}$ den nationella produktionen. Detta representerade den ursprungliga fördelningen. Sedan afstodo dessa participanter i den ursprungliga fördelningen vissa delar af sina andelar till samhällets öfriga medlemmar, resp. till staten, kommuner och andra korporationer. Denna ytterligare fördelning kallades för den härledda fördelningen, och på detta sätt kom man till en uppdelning af inkomsterna uti ursprungliga och härledda. I närmaste samband härmed stod uppdelningen af samhällets medlemmar i närande och tärande sådana. Till de förra räknades alla de som togo del i den ursprungliga fördelningen, skördade ursprungliga inkomster. När dessa inkomster konsumerades, kommo samhällets öfriga medlemmar jämte staten etc. att fả deltaga i konsumtionen af dessa inkomster, och de fungerade därför blott såsom tärande medlemmar, hvilka icke medverkade till att skapa den produkt, hvarifrån deras inkomster ursprungligen härflöto.

Detta betraktelsesätt innebär emellertid en hopblandning af olikartade företeelser. Det innebär först och främst en alltför snäf uppfattning af innehăllet $\mathrm{i}$ nationalprodukten. Denna omfattar nämligen allt användbart af ekonomiskt värde som åstadkommes, hvad detta än må bestå i. Till nationalprodukten höra sålunda alla personliga tjänster $\mathrm{i}$ vidsträckt bemärkelse och alla prestationer af stat, kommuner och andra korporationer. Hela denna nationalprodukt uppdelas sedermera på samhällets medlemmar. Detta sker merendels $\mathrm{i}$ formen af byten, direkta eller förmedlade genom penningar. Genom dylika byten får $\mathrm{A}$ en del af hvad $\mathrm{B}, \mathrm{C}, \mathrm{D}$ etc. åstadkommit, $\mathrm{B}$ en del af hvad A, C, D etc. åstadkommit o. s. v. Alla dessa, som să- 
lunda lämna ekvivalenter för hvad de af andra mottaga, ha lika verkliga, ursprungliga inkomster. Läkare, ämbetsmän, tjänstehjon $\mathrm{m}$. fl. höra likaväl som arbetare, kapitalister etc. till samhällets närande medlemmar, $\mathrm{i}$ den mån de med ekvivalenta prestationer betala hvad de få i ekonomiska nyttigheter. Samma gäller om staten och kommuner; dessa få visserligen till väsentlig del sina inkomster från de skattdragande, men staten och kommuner fullgöra prestationer, som ingå $\mathrm{i}$ nationalprodukten och utgöra ekvivalenter för de inkomster de uppbära.

$\AA$ andra sidan finnas också inkomster, som äro härledda i ofvannämnda bemärkelse, d. v. s. som uppstå därigenom att en person utan ekvivalent afstår en del af sin inkomst till en annan. Det vanligaste exemplet härpå är, att en person lämnar åt en annan årligt understöd. Men äfven andra exempel förekomma, ehuru sakförhållandet därvid ej framträder så tydligt. När en vara fördyras genom en på densamma lagd skatt, utgör varan ej full ekvivalent för den erlagda betalningen, utan en del af denna senare utgör skatt till staten, d. v. s. betalning för af staten presterade tjänster. Om nu i stället varans fördyrande möjliggöres genom att tillverkaren innehar monopol på tillverkningen, blir ofta förhållandet detsamma som om köparen hade att till tillverkaren erlägga en skatt, ${ }^{1}$ som dock därvid ej motsvaras af en motprestation från tillverkarens sida, såsom förhållandet är vid verkliga skatter till staten. I dylika fall är tillverkarens inkomst till en del att rubricera såsom härledd. Andra dylika fall förekomma vid spekulationsaffärer, då prisen för föremålen för dessa affärer uppdrifvas utöfver deras verkliga värden. Under krigsåren ha dylika i förklädd form uppträdande härledda inkomster som bekant förekommit i riklig mängd.

Kriteriet på att en inkomst är ursprunglig i nyssnämnda bemärkelse kan sålunda sägas vara, att inkomsten erhålles på grund af en prestation af ekonomiskt värde. Med tillämpning af detta kriterium är alltsă utdelningen till aktieägarna en ursprunglig inkomst och icke en härledd; den är ej någon gåfva af aktiebolaget till aktieägarna. Men häraf följer icke, att, om t. ex. ett aktiebolag har en vinst af 100,000 kronor och däraf utdelar till aktieägarna 60,000 kronor, bolaget och aktieägarna tillsammans ha en inkomst af 160,000 kronor. I det fall åter, som Dehlinger använder för att bevisa sistnämnda (falska) sats, är förhållandet ett annat. Om t. ex. arbetarna $i$ en stad uppbära $i$ arbetslöner $I$ mill. kronor och biograferna i samma stad genom arbetarnas besök ha en inkomst af 20,000 kronor, så ha arbetarna och biograferna tillsammans en inkomst af $1,020,000$ kronor. Men häraf följer icke, att, om ett aktiebolag har en vinst af 100,000 kronor och aktieägarna få $\mathrm{i}$ utdelning uppbära 60,000 kronor, aktiebolaget och aktieägarna tillsammans ha en inkomst af 160,000 kronor. Denna olikhet beror på följande förhållande. Arbetarnas inkomster

1 Förhållandet betecknas $\mathrm{i}$ det vanliga språkbruket såsom en brandskattning af köparna af varan. 
äro oberoende af biografernas prestationer; arbetarnas inkomster bero på deras arbete i fabrikerna, biografernas prestationer inverka ej på storleken af arbetarnas löner. Aktiebolagets s. k. inkomst åter beror på d. v. s. skapas förmedelst aktieägarnas prestation, som består däri, att de ställa kapital till bolagets disposition. När ett aktiebolag åstadkommit en inkomst af I00,000 kronor, har detta resultat möjliggjorts endast genom aktieägarnas kapitalinsats. Aktiebolaget och aktieägarna tillsammans ha sålunda i detta fall icke mer än $100,000 \mathrm{i}$ inkomst.

Till felet $\mathrm{i}$ Dehlingers resonemang har bidragit, att han låtit förvirra sig af ett oegentligt språkbruk, som fătt insteg bl. a. i vår inkomstskattelagstiftning, nämligen att beteckna ett bolags vinst med termen inkomst. Ett bolags eller i allmänhet en associations vinst är $\mathrm{i}$ grunden intet annat än afkastningen af associationens rörelse. Denna afkastning fördelas sedan i inkomster för olika personer. Detta framträder tydligast i en på kooperativ grund organiserad association. Associationens verksamhet ger en afkastning, som fördelas mellan arbetarna, kapitalisterna och företagarna och därigenom uppstå inkomster för dessa tre kategorier. Betecknas nu associationens afkastning eller vinst såsom inkomst, får man naturligtvis ej upptaga associationens inkomst vid sidan af arbetarnas, kapitalisternas och företagarnas inkomster från associationen. Men det är detta felaktiga resonemang, som Dehlinger gör sig skyldig till. Om ett aktiebolag anskaffat ett kapital genom upplåning och afkastningen uppgår till 100,000 kronor och skuldräntorna till 60,000 kronor, så ha ju aktiebolaget och bolagets borgenärer tillsammans dock blott 100,000 kronor i intäkt. Om nu aktiebolagets borgenärer gå in pă att utbyta sina fordringar mot aktier i bolaget, så att i stället för 60,000 kronor skuldräntor till borgenärerna träda $60,000 \mathrm{kr}$. utdelning till aktieägarna, så kan ju detta ej ändra den sammanlagda intäkten: äfven om man betraktar aktiebolaget och aktieägarna såsom helt skilda ekonomiska subjekt, blir förhållandet att aktiebolaget och aktieägarna tillsammans ha en intäkt af blott I00,000 kronor.

När denna regel för aktiebolags beskattning genom inkomstskatt tilllämpas, föreligger sakligt sedt dubbel beskattning i större eller mindre omfattning, allt efter den relativa storleken af utdelningen till aktieägarna. Därjämte följa sakliga oegentligheter och formella svårigheter af den princip som denna regel innebär, nämligen att aktieägarna bli skattskyldiga för bolagets vinst först då denna vinst utdelas till aktieägarna. Denna princip hvilar på det antagandet, att aktieägarna ej komma i åtnjutande af aktiebolagets vinst annat än $\mathrm{i}$ den mån vinsten utdelas. Detta antagande är icke riktigt. Aktieägarna kunna komma i åtnjutande af bolagets vinst på två sätt, nämligen dels genom utdelning af vinsten, dels genom att aktiernas värde stiger, $i$ analogi med förhållandet inom ett handelsbolag. Visserligen ha aktieägarna ej năgon rätt till att få vinsten utdelad, 
såsom fallet är med delägarna $\mathrm{i}$ handelsbolaget, ${ }^{1}$ utan det tillkommer bolagsstämman att fritt bestämma, om utdelning skall ske och huru stor den skall blifva. Men aktieägarna ha full säkerhet för att bolagets vinst skall komma dem tillgodo antingen genom utdelning eller dess bevarande åt bolaget : ${ }^{2}$ i den mån vinsten ej utdelas, kommer den att bevaras åt bolaget, hvars kapitaltillgångar bli ökade och därigenom ökas värdet af aktierna $\mathrm{i}$ bolaget. Det afgörande momentet är sålunda, att bolaget skördar vinst. Hur denna vinst disponeras, om den utdelas till aktieägarna eller bevaras åt bolaget är icke af afgörande betydelse för om aktieägarna komma $\mathrm{i}$ åtnjutande af vinsten eller ej. Vissa ifrågasatta modifikationer af eller undantag från denna sats skola strax beröras.

$\mathrm{Om}$ nu utdelningen af bolagets vinst uppskjutes, kunna oegentligheter vid beskattningen uppstå såsom följd af att aktieägare ej beskattas för andel $\mathrm{i}$ bolags vinst förrän denna vinst utdelas, nämligen $\mathrm{i}$ den mån aktier ombytt ägare. Ett aktiebolag med ett aktiekapital af I mill. kronor har ett år en vinst af 300,000 kronor. Bolaget utdelar 100,000 kronor och reserverar till framtida disposition 200,000 kronor. I följd däraf stiga aktierna från pari till 20 procent öfver pari. Några år därefter gör bolaget en extra utdelning af dessa 200,000 kronor, och då få aktieägarna erlägga inkomstskatt för denna utdelning. Sedan denna utdelning skett, sjunka aktiernas värde åter till pari. De aktieägare, som köpt aktier efter det de stigit, få sålunda ej någon förmögenhetsökning genom utdelningen, enär värdet å deras aktier sjunker med samma belopp som utdelningen, men de få ändock erlägga skatt för utdelningen. De åter, som, sålt sina aktier före den extra utdelningen, ha skördat vinsten af dessa utdelningar ( $\mathrm{i}$ form af ökning af deras aktiers värde) men undgå skatt för denna vinst. Samma förhållande äger rum, om aktiebolag, som upplöses, samlat stora reserver af vinstmedel; skulle dessa vinstmedel beskattas då de utdelas, skulle nyssnämnda resultat i stor omfattning inträda. ${ }^{3}$

Det händer emellertid ibland, att $\mathrm{i}$ verkligheten förloppet ej blir det nyss skildrade, beroende på att de i aktiebolagen styrande lyckas dölja tillvaron af vinst, hvaraf följden blir att aktierna komma att säljas till priser, som understiga deras verkliga värden. I särskilda fall kunna därför för-

1 Se 1895 års lag om handelsbblag $\iint$ Io-I 2.

2 Lag om aktiebolag $\int \$ 53-55$ och $\$$ II4.

3 Detta förhållande har föranledt den hos oss gällande praxis (grundad på ett uttalande af finansministern under förarbetena till 19 10 års inkomstskattelag) att utdelning af reserverade vinstmedel vid bolags upplösning ej $i$ beskattningshänseende likställes med annan utdelning från bolaget. Skattskyldighet för utdelning af såväl ursprungligen tillskjutna kapitalbelopp som reserverade vinstmedel eller annat som bolaget vid upplösningen äger behandlas lika och bedömes efter de för realisationsvinst gällande reglerna, därvid det under upplösning varande bolaget fingeras köpa aktierna för en köpeskilling pr aktie motsvarande den på aktien belöpande andelen i bolagets tillgångar. Äfven om bolagets tillgångar vid upplösningen ej öfverstiga det ursprungligen inbetaldta aktiekapitalet, kan aktieägare ändock bli skattskyldig, nämligen om han förvärfvat aktien till ett pris under det nominella beloppet. 
hållandena vara sådana, att den här ofvan angifna verkan ej inträder, utan att, trots det att aktier ombyta ägare, skatten för den extra utdelningen kommer att träffa aktieägarna, i den mån de verkligen komma i åtnjutande af bolagets vinst. Men dels beror det på en lycklig slump, om det sistnämnda kommer att väsentligen inträffa, dels är det ju ej lämpligt att bygga en skattelagstiftning på förutsättningen af dylika förkastliga manipulationer af bolagsstyrelser, hvilka ha öfvervägande skadliga verkningar och därför borde förhindras.

Nämnda föreskrift, att aktieägares andel i aktiebolags vinst ej beskattas förr än utdelning af vinsten äger rum, är grunden till den bekanta tvistefrågan om utdelning af gratisaktier. Orimligheten $\mathrm{i}$ tanken att beskatta dylik utdelning af aktier beror ej egentligen på att anordningen ej kan betraktas såsom utdelning, därför att aktiebolaget ej afstår från någon del af sina tillgångar, utan det afgörande är, att aktieägarna redan kommit $\mathrm{i}$ åtnjutande af den vinst, som möjliggör utdelningen af gratisaktier; aktiernas värde har stigit $i$ följd af reserverandet åt bolaget af vinsten, och utdelningen af gratisaktier har blott en formell betydelse: det värde, som förut representerades af ett visst antal aktier, motsvaras efter gratisutdelningen af ett större antal aktier. Men i sak innebär detta detsamma som om aktiernas nominella belopp nedsatts och antalet aktier i stället ökats. Aktiernas nominella belopp betyder intet för aktieägarnas rättsställning, utan har tillkommit blott och bart för att till allmänhetens kännedom bringa storleken af penningvärdet af det öfverskott af bolagets tillgångar utöfver dess skulder, som enligt lag skall bibehållas oförminskadt så länge bolaget består, där ej lagen medger undantag härifrån och förutsättningarna för dessa undantag uppfyllas. Aktieägarnas rättsställning skulle sålunda vara oförändrad, om aktierna ej lydde på något bestämdt belopp utan blott angåfvos såsom bråkdelar af bolaget, såsom fallet ursprungligen var beträffande Stora Kopparbergs bergslags aktiebolag. I ett efter denna grund organiseradt aktiebolag vore en åtgärd motsvarande utdelning af gratisaktier helt enkelt omöjlig på annat sätt än att den kvotdel, som hvarje aktie representerade, minskades i motsvarande grad; antalet kvotdelar i ett gifvet helt kan ju ej ökas, utan att kvotdelarnas storlek i motsvarande grad minskas.

II) Aktieägarna betraktas såsom delägare i aktiebolaget på väsentligen samma sätt som bolagsmännen $i$ ett handelsbolag i förhållande till handelsbolaget. Aktiebolagets s. k. inkomst blir då aktieägarnas inkomst. Konsekvensen af denna uppfattning blir, att aktieägarna böra beskattas enhvar för den del af aktiebolagets vinst, som motsvarar hans andel i aktiebolaget, d. v. s. proportionen mellan hans aktieinnehaf och hela antalet aktier i aktiebolaget. Huruvida aktiebolagets vinst utdelas eller ej, inverkar alltså ej på aktieägarnas skattskyldighet. Aktiebolaget såsom sådant beskattas 
ej med inkomstskatt. Dessa regler tillämpas, som bekant, beträffande beskattning af handelsbolags vinst.

Denna regel öfverensstämmer bäst såväl med naturen af det ekonomiska förhållandet mellan aktiebolaget och aktieägarna som med inkomstskattens karaktär. Att beskatta aktiebolaget såsom sådant genom en progressiv inkomstskatt är icke förenligt med inkomstskattens väsen. Denna skatt afser ju att beskatta alla efter deras skatteförmåga. Om det rätta uttrycket för denna skatteförmåga råder visserligen i flera viktiga punkter olika meningar. Men dessa beröra ej den här föreliggande frågan. Att en progressiv inkomstskatt icke lämpar sig för att tillämpa på ett aktiebolags beskattning, framgår ju däraf att, om samma rörelse $i$ samma omfattning och med samma resultat drefves af tio små bolag eller af ett stort med samma kapital som de tio tillsammans, det större skulle komma att beskattas hårdare än de tio små. I en progressiv inkomstskatt bör sålunda aktiebolags vinst endast beskattas hos aktieägarna. Skulle det finnas anledning till att beskatta inkomst från aktiebolag hårdare än annan inkomst, så bör detta alltså ske i den formen, att de, som uppbära inkomst från aktiebolag, för denna del af sin inkomst beskattas tyngre än för annan slags inkomst, på samma sätt sålunda som inkomst af förmögenhet beskattas tyngre än annan inkomst. Man skulle då få två gradationer af skattefoten vid inkomstskatten vid sidan af skattefotens gradering enligt inkomstens storlek, nämligen dels högre skatt på inkomst af förmögenhet (som ju också drabbar inkomst af aktier), dels högre skatt på inkomst från aktiebolag. Formuleras emellertid problemet på detta sätt, lär det väl vara omöjligt att bevisa, att inkomstskattens principer skulle fordra en dylik extra beskattning af inkomst från aktiebolag.

En helt annan sak är, att det kunde komma ifråga att vid sidan af inkomstskatten och alldeles oberoende af densamma införa en särskild skatt på aktiebolag. Därvid bör först den synpunkt, ur hvilken en dylik särskild beskattning af aktiebolag är påkallad, fixeras, och därefter reglerna för denna särskilda beskattning fastställas på grund af dessa skäl till beskattning.

I vår lagstiftning beskattas visserligen aktiebolagen efter andra grunder än som gälla för andra skattskyldiga. Men denna beskattning uppfyller ej de fordringar, som nyss uppställts. Den grund, hvarpå denna beskattning hvilar, är aldrig riktigt klargjord. Den beskattar alla bolag med en skatt, som står i förhållande till bolagens vinst, men så, att skatten till en viss gräns växer i samma mån som vinsten utgör en större procent af bolagets kapital. Detta är ju en särskild synpunkt för beskattning af aktiebolag med en särskild skatt. Om den grunden är riktig eller tillräcklig, lämnar jag här därhän. Men därmed är denna beskattnings funktion ej fullständigt angifven. Den har äfven till uppgif́t att komplettera inkomstbeskattningen af aktieägarnas utdelning från bolaget, enär denna utdelning ej omfattar bolagets hela vinst. Denna särskilda beskatt- 
ning har sålunda två uppgifter, som egentligen äro oförenliga. Skulle meningen vara att, såsom $\mathrm{i}$ den kungliga propositionen till 1918 års riksdag antyddes, söka fă aktiebolagets hela vinst beskattad hos aktieägarna, bortfölle den ena uppgiften för denna skatt, och då borde reglerna för densamma underkastas en förnyad pröfning och revision.

Är inkomstskatten proportionell, bortfalla de väsentligaste oegentligheterna hos en beskattning af aktiebolaget i stället för aktieägarna. De kvarstående äro, att inkomst kan komma att beskattas, ehuru den är för liten, eller att inkomst, som bort beskattas, undgår beskattning. Äfven om dessa fel ej utan alltför stor apparat kunna undanröjas, väga dock dessa oegentligheter föga $\mathrm{i}$ jämförelse med den stora fördelen att utan alltför mycket arbete kunna med tillbörlig skatt träffa all inkomst från aktiebolagen. Att i detta fall belägga ej blott aktiebolaget utan äfven aktieägarna med inkomstskatt är, såsom visats, obefogadt. Det vore också på grund af det nyss sagda synnerligen opraktiskt att beskatta aktieägarna jämte aktiebolaget. Anses aktiebolagets vinst ej vara tillräckligt hårdt beskattad genom inkomstskatt efter den vanliga skattefoten, så är det ju enklast att för aktiebolagen tillämpa en dubbelt så hög skattefot i stället för att vid sidan af aktiebolagets beskattning inrätta en beskattning af aktieägarna. Men det förra sättet skulle nog verka stötande, och detta är ett godt stöd emot den dubbla beskattningen af aktiebolags vinst öfverhufvud.

Det sagda gäller sålunda om vår kommunala inkomstbeskattning, som är grundad på proportionell skattefot. Något giltigt skäl att kommunalt beskatta både aktiebolaget och aktieägarna genom inkomstskatt förefinnes icke. Däremot kunde med hänsyn till den interkommunala beskattningsrätten det ifrågasättas att beskatta aktieägarna för utdelningen och aktiebolaget för resten af vinsten.

Skulle vid sidan af aktieägarnas beskattning för aktiebolagets vinst genom en statsinkomstskatt en särskild statsskatt å aktiebolagen anses ur den ena eller andra synpunkten påkallad, blir det ett särskildt problem att lösa, om äfven kommunerna böra få pålägga aktiebolagen en dylik särskild skatt. Men detta problem måste lösas med hänsyn till den särskilda grunden till att en dylik statsskatt anses böra påläggas. Alla statsskatter passa ju ej inom det kommunala skattesystemets ram.

Om det nu ock måste erkännas, att inkomstskattens grundtanke kräfver, att aktieägarna beskattas enhvar för sin andel i aktiebolagets hela vinst och ej blott för utdelningen, återstår att undersöka, om denna anordning är praktiskt utförbar.

I sakligt afseende är föga att anmärka mot denna anordning, om man nämligen städse fasthåller vid att valet står mellan att beskatta aktieägarna endast för utdelningen eller för bolagets hela vinst. De ojämnheter och brister, som äro en följd af att aktieägarna öfverhufvud beskat- 
tas för bolagets vinst, făr sålunda ej bokföras såsom brister hos metoden att beskatta aktieägarna för bolagets hela vinst. Det är här fråga om sådana brister, som ha sin grund $\mathrm{i}$ att aktier ofta byta ägare. I inkomstskattens natur ligger att beskatta den inkomst, hvarje skattskyldig verkligen åtnjutit. Men när det gäller beskattning af inkomst af aktier, måste af praktiska skäl beskattningen påföras den, som af bolaget uppbär utdelningen för aktierna, ehuru det ej är säkert att det är denna person, som verkligen uppburit utdelningen såsom inkomst; han kan ha erlagt betalning för utdelningen vid köpet af aktierna, så att det $i$ verkligheten är säljaren af aktierna, som kommit i åtnjutande af den inkomst, som utdelningen representerar, och icke den som vid utdelningens utfallande var ägare till aktierna. Men detta missförhållande är praktiskt taget förenadt med hvarje anordning, enligt hvilken aktieägarna beskattas för aktiebolags vinst, och kan därför ej utan vidare anföras såsom skäl emot att aktieägarna påföras beskattning för bolagets hela vinst och ej blott för utdelningen.

I den ofvannämnda regeringspropositionen till I9I8 års riksdag anföres såsom skäl emot anordningen, att den kunde verka skadligt för sådana innehafvare af aktier $\mathrm{i}$ ett bolag, som för sin utkomst äro beroende af utdelningen af dessa aktier. Det heter där:

»Helt annorlunda ställer sig däremot förhållandet $\mathrm{i}$ fråga om den, som äger ett mindre antal aktier, måhända $i$ ett och samma bolag. Han kan ej afgörande inverka på- frågan, huruvida eller till hvilket belopp utdelning skall ske. Redan nu torde det förekomma, att en ekonomiskt mera uthållig majoritet bland aktieägarna $\mathrm{i}$ ett bolag besluter innehålla utdelning år efter år för att förmå de mindre aktieägarna, hvilka hafva svårare att undvara den årliga räntan å sitt kapital, att slutligen sälja sina aktier, understundom till underpris. Förvisso komma sistnämnda aktieägare $\mathrm{i}$ en än sämre ställning, om de blefve skyldiga att årligen betala skatt för en inkomst, som ej vore åtkomlig för dem.»

Denna invändning lider $\mathrm{i}$ främsta rummet af det felet, att den förbiser att, om vid beskattningens anordnande hänsyn skall tagas till dylika petitesser, det blir omöjligt att åstadkomma en $i$ det stora hela rationell beskattning, och detta gäller särskildt i fråga om det här förevarande särdeles intrikata beskattningsproblemet. För öfrigt förbises att den ifrågasatta anordningens genomförande skulle främja en riktigare uppskattning af aktiernas verkliga värden och därigenom vara till fördel för aktieägare $\mathrm{i}$ den påpekade ställningen. Slutligen utöfvar litet mer eller mindre skatt ej på långt när en så afgörande inverkan på dylika aktieägares intresse, som innehållandet af utdelning, som kunde ske, eller andra manipulationer från en aktiemajoritets sida för att brandskatta minoriteten.

De egentliga svårigheterna äro ej af saklig natur, utan gälla möjligheten att utföra detta beskattningssätt. Därvid äro flera omständigheter att beakta. 
Den utdelning å aktier, som t. ex. innevarande år, I9I9, blir föremål för beskattning, är den som skedde år 1918 och sålunda tages ur den vinst, som resp. aktiebolag intjänade under år 1917. Beskattas bolagets vinst uteslutande genom inkomstskatt å aktieägarna, kunde det synas oegentligt att lägga en så lång tid mellan förvärfvet af vinsten och dess beskattning. Men denna oegentlighet torde af praktiska hänsyn ej kunna undanröjas.

Beskattningsförfarandet I 19 I9 skulle försiggå på följande sätt. Aktiebolagen uppgifva, hvilka personer uppburit utdelning från dem och för hvilket antal aktier, samt meddela därjämte det beskattningsbara beloppet af den vinst, som bolaget haft under 19I7 och som fastställts genom taxeringen I9I8. Aktieägarna deklarera liksom nu sina utdelningar, men böra därjämte åläggas uppgifva antalet aktier de inneha i hvarje bolag; uppgift härom skall ju beskattningsmyndigheten få från aktiebolagen, så att denna uppgift från aktieägarna, som behöfs för kontrollen, icke innebär något ytterligare blottande af deras affärshemligheter. Med ledning af dessa uppgifter blir det möjligt att bestämma det belopp aktievinst, för hvilket hvarje skattskyldig skall taxeras.

Så långt äro svårigheterna väl lätt öfverkomliga. Men denna taxering öfverensstämmer sålunda så godt som aldrig med de skattskyldigas uppgifter om deras inkomsters belopp. Enligt nu gällande regler skulle därför alla aktieägare erhålla underrättelse om sin taxering frăn taxeringsnämnderna, då ju taxeringarna alltid komma att afvika från de skattskyldigas uppgifter. Detta medför ju ökadt besvär, som ibland kan bli mycket stort.

Vidare är att beakta, att för närvarande aktieägare bli skattskyldiga för allt som utdelas utan hänsyn till, om det utdelade härrör af vinst, som enligt de gällande reglerna är att räkna till beskattningsbar inkomst eller till kapitalförvärf. Skall denna princip fortfarande tillämpas, uppstår en synnerligen betydande svårighet, mindre $\mathrm{i}$ formellt hänseende (ty bolaget skulle då uppgifva äfven rena kapitalförvärf), men i materiellt hänseende; aktieägarna skulle bli underkastade ibland en i förhållande till utdelningen enormt hög skatt, som under nuvarande anordning ej skulle komma i fråga förr än vid bolagets upplösning och i regeln ej ens då. Rättast vore dock att ändra denna princip, som ju är i grunden orättvis, om den ej utsträckes till alla skattskyldiga.

Slutligen kräfves en strängare kontroll öfver att rätta uppgifter om alla aktieägare aflämnas och att beräkningen af bolagens vinst sker i öfverensstämmelse med gällande föreskrifter.

Dessa svårigheter, som här endast kunnat skisseras, kunna ju visa sig vara så stora, att beskattningen af aktiebolagens vinster ej lämpligen kan byggas på denna grund. I så fall măste man med resignation finna sig i nuvarande, på mot hvarandra stridande principer byggda anordning och lăta vederbörande anstränga sitt skarpsinne för att åvägabringa största möjliga förnuft $i$ den valda anordningen. 